\title{
BAIL-IN AND PROSPECTS FOR APPLICATION IN RUSSIA
}

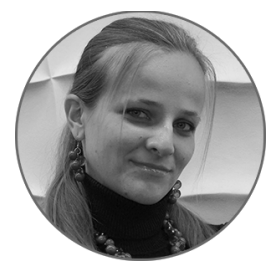

Article history:

Received 20 June 2016

Received in revised form

2 December 2016

Accepted 19 December 2016

Translated 25 May 2017

Available online 15 June 2017

JEL classification: $\mathrm{G} 21, \mathrm{G} 28$

Keywords: bail-in, Deposit Insurance Agency, rating, bailout, financial restructuring

\section{Elena V. KORNILOVA}

Financial University under Government of Russian Federation, Moscow, Russian Federation goldfi@bk.ru

\begin{abstract}
Importance The article analyzes the practices and trends in using the bail-in mechanism in the world.

Objectives The aim is to review the possibility of applying the bail-in mechanism in Russia and its efficiency based on the analysis of best practices, consider alternatives and influence of the mechanism on rating of financial institutions.

Methods The study draws on general and specific methods of scientific knowledge, i.e. empirical investigation (comparison, data collection and analysis), comparative examination, and synthesis of theoretical and practical material. To process and systematize the information, I used grouping, classification and a systems approach.

Results The study reveals that the new rules are intended to streamline the system of troubled banks' restructuring and liquidation. The bail-in mechanism has appeared recently, therefore, the experience in its application is not extensive.

Conclusions and Relevance It is not clear yet how to determine the date and amount of conversion. The issue of the price of funds conversion into equity is controversial. Another complex issue is the impact of bail-in on the rating assigned by international agencies.
\end{abstract}

The editor-in-charge of this article was Irina M. Komarova

Authorized translation by Irina M. Komarova

Stable operation of the Russian banks faced significant threats during the 2008 financial crisis, still remaining a very topical and acute issue. The crisis of global financial markets revealed that banks were not prepared for negative market trends and incapable of managing the market risk on their own (because it was credit institutions' responsibility to manage risks [1]). The crisis also highlighted shortcomings of regulators and the credit industry, as a whole [2]. Banks are expected to provide quality services to their customers. However, these objectives are not met by all banks equally. As a result, they lose their licenses [3]. The Russian laws convey to the Central Bank of Russia special authority and functions, thus broadly empowering it to influence operations of credit institutions [4]. The banking sector subsequently saw a recall of licenses from more than 90 banks in $2015^{1}$. For instance, the Central Bank of Russia revoked more licenses from 2010 through 2015 (Fig. 1). Most analysts agree this trend will be persistent. V. Aksakov, Local Director of BKS Premier Bank, justifies the policy of the Central Bank of Russia, saying that weak banking institutions may shatter the overall banking sector in the unstable economic situation. He presumes the number of banks may fall down to 500 in the years to come ${ }^{2}$.

\footnotetext{
${ }^{1}$ Belova S.A. [Banking system of contemporary Russia]. Vestnik Novgorodskogo filiala RANKhIGS = Bulletin of Novgorod Branch of RANEPA, 2016, vol. 1, no. 5-1, pp. 9-13. (In Russ.)

${ }^{2}$ Eksperty prognoziruyut novuyu volnu otzyvov litsenzii u krupnykh bankov [Experts predict a new turn of license recall from major banks]. Available at: http://www.dp.ru/a/2015/08/20/Bankopad_prognozi (In Russ.)
} 
However, there are opponents to the policy of the Central Bank of Russia. For instance, Igor' Suzdal'tsev, CEO of the History, Economics and Law Research Institute, believes the Central Bank of Russia should stop recalling licenses, since the population always pays attention to such practices. It may result in massive outflows of deposits from the banking sector, notwithstanding the existing deposit insurance commitments. In his expert opinion, recalls of banking licenses may entail other hazards. In particular, it may cause a decrease in corporate and retail banking services. He reckons it is unreasonable for the Central Bank to think that 1,000 banks are too much. Over 7,000 banking institutions operate in such developed economies as the EU and the USA and they attract their particular clientele ${ }^{3}$.

Depositors' needs and concerns should not be neglected and regarded as secondary matters. Those concerns stem from the license recalling practices and general reduction in the number of banks. It primarily relates to the historically originated practice that traces back to the Soviet times, when deposits were one of the most popular ways of money saving. According to the National Agency for Financial Research's analysis (NAFI), currently, savings of 60 percent of Russians will cover as many as three months of living, while savings of 20 percent of people will be sufficient for one month only [5]. If we look at how the deposit placement system has been reformed for the recent 20 to 25 years, we will definitely note deposits got more secured. In the 1990s, people lost all their deposits in case of the bank's insolvency. In 2004, the Russian government adopted the deposit insurance system [6]. The idea is simple. If the bank goes bankrupt, the Deposit Insurance Agency reimburses the depositor's funds within the amount of RUB 1.4 million. Deposit insurance systems have been created in many countries for the recent 20 years (2013: 111 countries) [7]. During the global financial crisis, such systems mainly helped to secure money of depositors [8]. As of February 2015, over 850 banks joined the deposit insurance system in Russia [9]. The system has been working successfully in Russia from its onset, however it faced certain difficulties when the Central Bank of Russia started purging the banking sector. As of 1 January 2016, the amount of reimbursements increased more than 34 times as compared with 2010 (Fig. 2).

\footnotetext{
${ }^{3}$ Prestuplenie protiv ekonomiki. Chem opasen otzyv litsenzii u bankov [A crime against economy. What threats do recalls of banks' licenses pose?]. Available at http://www.aif.ru/money/economy/1027236 (In Russ.)
}

As the situation aggravated, new concerns were raised in relation to operations of the Deposit Insurance Agency and ways to alleviate its burden. German Gref, Head of Sberbank of Russia, offered several solutions to make the burden of the Deposit Insurance Agency more bearable:

- pay the compensation from the Deposit Insurance Agency's funds, only once in a lifetime [10];

- set up the life-long limit of reimbursements in the amount of RUB 3 million;

- provide reimbursement no more than once in five years ${ }^{4}$.

Such proposals rely upon an analysis of insurance payments and identification of the so called serial depositors. The term serial depositor refers to people who place their money with banks at the high interest rate within amounts covered by insurance plans. In this case, the main risk relates to the intention to derive big income without considering the financial standing of the bank. The proposals were not approved. As Elvira Nabiullina, Head of the Central Bank of Russia, says, the Deposit Insurance Agency will always have an access to a line of credit from the Central Bank. The Deposit Insurance Agency got this opportunity in April 2014 after amendments were introduced into Federal Laws, On Insurance of Private Deposits in Banks of the Russian Federation, and, On the Central Bank of the Russian Federation (Bank of Russia) [11].

Nevertheless, in 2016, Russia's Deposit Insurance Agency pronounced a new method for failing bank resolution, i.e. bail-in. This tool will help to avoid license recalling. It would be interesting to analyze this mechanism and its efficiency. Bail-in implies that third-tier creditors' claims will be forcibly converted into subordinated loans or the bank's authorized capital ${ }^{5}$. Bail-in should lead to lowering investment in risk-exposed assets, since the investor will bear equal losses with the bank in case of financial challenges. According to the Deposit Insurance Agency, the mechanism allows to save budgetary funds in case of the additional capitalization of the bank, and ensures higher security of private funds (since the bank

\footnotetext{
${ }^{4}$ Khvatit li deneg $v$ fonde strakhovaniya vkladov? [Does the deposit insurance fund have enough money?]. Available at: http://www.kp.ru/daily/26391/3268769 (In Russ.)

${ }^{5}$ ASV khochet dobavit'v skhemy sanatsii bankov takie mekhanizmy, kak bridzh-bank I bail-in bankov [Deposit Insurance Agency wants to introduce such mechanisms as a bridge bank and bail-in banks into the resolution schemes]. Available at: http://www.banki.ru/news/lenta/? id=7826497 (In Russ.)
} 
continues its operations without inducing any insurance payments) ${ }^{6}$.

Russia's Ministry of Finance is currently studying the application of the mechanism in Russia. The analysis stalls when it comes to the question, What deposits should be qualified as large - over RUB 100 million or RUB 50 million, or even RUB 10 million?' Depending on these thresholds, the scope of the law may embrace more or less people and entities. It is not yet clear about uninsured deposits and corporate accounts. These issues are expected to be resolved by the legislature ${ }^{7}$. It is worth mentioning that in February 2016, the Deposit Insurance Agency protested against applying the bail-in procedure to individuals.

What does the bail-in mechanism stand for? How and where does it work? The bail-in mechanism attracted common attention worldwide after it was applied in Cyprus during the 2012-2013 banking crisis [12]. In fact, bail-in means that a stakeholder transfers his/her wealth to the banks so to support the bank's solvency. The idea is simple. When a big bank goes bankrupt, shareholders may also bear substantial losses. So, if their deposits turn to be insufficient to rescue the bank, large deposits will be taken out. An identical scheme is used in Cyprus ${ }^{8}$. Hence, the bail-in mechanism is a concise form of bank restructuring [13].

Discussions engendering this mechanism originated during the 2008 crisis when national governments had to contribute billions of U.S. dollars for rescuing and recoverying large international banks. To avoid such situation in the future, financial regulators worldwide decided to search for new and more effective methods for risk management on the part of large financial institutions. Following continuous discussions and debates, they formulated two possible options, i.e. contingent capital and involvement of those holding deposits/bonds into the financial resolution of banks debt conversion (bail-in) ${ }^{9}$.

\footnotetext{
${ }^{6}$ Ibid.

${ }^{7}$ Sobstvenniki ponevole: zachem nuzhen mekhanizm bail-in [Involuntary owners: Why is the bail-in mechanism needed?]. Available at: http://www.forbes.ru/mneniya-column/konkurentsiya/311655sobstvenniki-ponevole-zachem-nuzhen-mekhanizm-bail (In Russ.)

${ }^{8}$ Snyder M. Why Is the EU Forcing European Nations to Adopt 'BailIn' Legislation by the End of the Summer? Available at: http://theeconomiccollapseblog.com/archives/why-is-the-eu-forcingeuropean-nations-to-adopt-bail-in-legislation-by-the-end-of-thesummer

${ }^{9}$ Contingent Capital and Bail-In Debt: Tools for Bank Resolution. Bank of Canada's Report. Financial System Review, 2010, December.
}

Contingent capital refers to a debt instrument, which is converted into the capital when certain figures exceed their predetermined values ${ }^{10}$. For instance, it may include preferred stocks and subordinated debt liabilities, which are converted into ordinary capital under certain conditions. Such tools of contingent capital, in fact, represent contractual mechanisms, which are converted in accordance with terms of the investor's contract for acquisition of the financial instrument. That is, contributing funds to such instruments, the investor agrees with conversion parameters stipulated in the contract provided certain circumstances are in place, and expects to derive additional income, which depends on the conversion probability. As for restructuring debt under a bail-in, it constitutes a contractual mechanism applicable to the first-tier securities, which are not used to assess the minimum level of capital adequacy. Thus, the conversion trigger and timelines are key elements of the options in question, i.e. contingent capital and debt restructuring. Contingent capital is subdivided into two types: contingent capital converted after the point of the entity's non-viability (Gone-concern contingent capital), and contingent capital converted up until the point of the entity's non-viability (going-concern contingent capital). This point can refer to different indicators. For example, the capital ratio or a decline in the market value of the banks' shares below a certain level. Contingent capital converted after the point of non-viability and involvement of those holding deposits/bonds into the bank's financial resolution can be split into two mutually related objectives:

- supporting the resolution of the failing bank when it cannot get recapitalized with private sources by providing finance;

- assurance that capital owners and other suppliers of regulatory capital, like most shareholders of banks, face the risk of losses, even if the failing bank is closed or dissolved.

The above tools are considered by the Basel Committee that deals with practical preparation of regulatory reforms [14]. The Basel Committee reviewed the tools and chose the following approach to regulate banks' capital adequacy. All new instruments of regulatory capital, other than ordinary ones, should be qualified as contingent capital the company converts after the point of its non-viability. Thus, it can be conceptually stated

\footnotetext{
${ }^{10}$ Contingent Capital and Bail-In Glossary. Available at https://www.bba.org.uk/policy/financial-and-risk-policy/bankreform/loss-absorbency/contingent-capital-and-bail-in-glossary/
} 
that the regulator sets up requirements to the minimum capital adequacy, considering prudential risks associated with respective operations. Regulator may also promulgate levels of contingent capital and debt commitments that are to be forcibly converted if involved into the bank's resolution, so to avoid the bank's bankruptcy or the government induced resolution, given requirements to prudential capital appeared insufficient due to some reasons ${ }^{11}$.

In 2012, Federal Deposit Insurance Corporation (FDIC) and the Bank of England jointly drew up a paper outlining their joint strategy for control over major financial institutions in both countries ${ }^{12}$. Pronounced legislative amendments inter alia included provisions on a possible use of the bail-in mechanism:

- the tool will allow the UK authorities to recapitalize financial institutions by transferring their losses to shareholders and unsecured creditors' amounts;

- the mechanism will not require a bridge bank or appointed receivership;

- the bail-in mechanism stipulates that capital and debt securities are transferred from shareholders and securities holders to an appointed trustee. During the time needed to assess possible losses, the appointed trustee holds the securities. The company's securities cease to be listed for this period of time. Once the required recapitalization level is determined, the former owners are informed about the conditions of a bail-in, indicating everything about a write-down and/or conversion;

- the paper envisages the procedure and conditions for bail-in of holding companies, where this mechanism can be used for the parent company and resolution of the entire financial group.

The Government of Canada declared its attitude to the bail-in tool in Economic Action Plan 2013. As per this document, considering the need to manage and control risks of systemically important banks, which, if failed, may undermine the economy, the Government of Canada understands it is reasonable to adopt additional supervisory safeguards and review possible

\footnotetext{
${ }^{11}$ Contingent Capital and Bail-In Debt: Tools for Bank Resolution. Financial System Review, 2010, December, pp. 51-56.

${ }^{12}$ News Release. Resolving Globally Active, Systemically Important Financial Institutions, Bank of England, Federal Deposit Insurance Corporation, 2012. Available at:

http://www.bankofengland.co.uk/publications/Documents/news/2012/n r156.pdf
}

solutions that do not involve taxpayers' funds. Economic Action Plan 2013 also highlights key aspects of the new policy:

- systemically important banks are bound to meet special requirements to capital adequacy as set forth by the regulator;

- the Government suggests adopting the bail-in mechanism for systemically important banks. As the mechanism requires, in case of unfavorable circumstances and bank's capital depletion, the bank can be recapitalized and regain financial stability through rapid conversion of certain liabilities into the regulatory capital.

The Government of Canada strives to break the habit of investors and other market actors of believing unreasonably that systemically important banks are too-big-to-fail ${ }^{13}$. Crashes of such large banks entail systemic troubles for the banking sector and the national economy, as a whole. As supporters of the too-big-to-fail concept believe, the importance of some financial institutions is a kind of guarantee that they will be financially rescued by the State and/or the central bank [15]. It is logical to suppose that globally active and systemically important banks should have substantial opportunities and resources available for the resolution purposes so to cover losses and recapitalize themselves and organize the resolution process with the lowest risk for financial stability [16].

Problems of the banking sector also emerged in the European Union, where consequences of the financial crisis were substantial too. According to the IMF, European Commission and Eurostat, European banks incurred almost EUR 1 trillion in losses within 2007 through 2010 (18 percent of the EU GDP). Financial aid in the form of recapitalization amounted to EUR 591.9 million for the period from October 2008 through December 2012, net of bank guarantees [17].

During the meeting on 27 June 2013, the European group (an official meeting of Finance Ministers of the EU nations) adopted bail-in rules for the European Union, which relied upon the practice used in Cyprus. Thereby those holding unsecured bonds participate in covering losses until the bank is vested with the right to the aid through the European Stability Mechanism (ESM). The European Commission enshrined the bail-in rules

\footnotetext{
${ }^{13}$ Jobs growth and long-term prosperity of Government of Canada. Economic Action Plan 2013 - budget document. House of Commons, 2013, pp. 144-145. Available at:

http://www.budget.gc.ca/2013/doc/plan/budget2013-eng.pdf
} 
in the Bank Recovery and Resolution Directive that was to be implemented within 2016 through 2018.

In October 2013, during the Summit in Brussels, 28 member States promulgated the procedure and schedule for setting up the banking union. The procedure and schedule have two parts ${ }^{14}$ :

- creation of the single supervisory mechanism, which the European Central Bank (ECB) will employ to control 130 major banks in the EU;

- creation of the Single Resolution Mechanism. Before it comes into effect, the process will be governed in accordance with a special directive.

As envisioned by the European group, the third part will pursue further harmonization of the deposit guarantee system [18]. As stipulated in the directive, starting from 2018, banks' shareholders are the first whose funds will be used to cover losses of the insolvent bank, being followed by smaller and large holders of bonds and major depositors. Insured deposits (EUR 85,000-100,000) are excluded. Uninsured deposits of individuals and small businesses will receive a privileged status as part of bail-in as losses are accepted.

The above rules pursue the creation of an orderly system for restructuring and liquidation of failing banks. The European Stability Mechanism is intended for two extreme purposes. First, the ESM provides aid to the EU member States after some losses are apportioned to shareholders and creditors. Second, the EMS indirectly merges with the process only after the national resolution fund is utilized in the country where the failing bank is located. The ESM will provide funding to the member State, and the respective government will grant a loan to the failing bank and will be responsible for the loan repayment.

As per the directive, preventive measures and safeguards are also very important. Banks must furnish their supervisory authorities with plans reflecting what measures they will undertake if the economic situation deteriorates. In turn, supervisory authorities classify banks into several types, thus setting up the Minimum Loss Absorption Level - MREL ${ }^{15}$.

\footnotetext{
${ }^{14}$ Bankovskii soyuz ES: direktiva o sanatsii problemnykh bankov [The EU Banking Union: the Resolution Directive for failing banks]. Available at: http://blogs.trust.ua/economics/2013/10/24/1259/Bankovskii-souz ES-direktiva-o-sanacii-problemnih-bankov/

${ }^{15}$ Bankovskii soyuz ES: direktiva o sanatsii problemnykh bankov [The EU Banking Union: the Resolution Directive for failing banks]. Available at: http://blogs.trust.ua/economics/2013/10/24/1259/Bankovskii-souzES-direktiva-o-sanacii-problemnih-bankov/ (In Russ.)
}

However, things are not that simple in this case. In May 2015, the European Commission warned 11 EU member countries and ruled to implement new bail-in rules within two months. Otherwise, the European Commission could resort to the Court of Justice of the European Union to hear the proceedings about the violation of the directive implementation timelines ${ }^{16}$. The directive implementation was delayed because such legal enactments meant that neither bank account was completely secure from withdrawal in case of the bank's bankruptcy.

There are several alternatives to bail-in as proposed by some scholars, economists, etc. For instance, quick sale of assets (absorption). This option was offered by Paul Melaschenko and Noel Reynolds [19] in A Template for Recapitalising Too-Big-to-Fail Banks. They say all assets and some liabilities of the parent company are transferred into receivership to a provisional holding company, which will be steering the operations within several months until the buyer is found. Proceeds from sale are used to reimburse amounts due to creditors likewise in bankruptcy proceedings. Unlike the bail-in tool, this option, however, assumes the bank is compliant with the antimonopoly laws and there is a competitive market for corporate control.

Notwithstanding the above difficulties, assets can be sold and the failing bank can be absorbed by other bank provided that the absorbing bank is stable or propped up. Examples can be seen in 2008. JP Morgan Chase Bank acquired Bear Stearns and Washington Mutual Bank. Wells Fargo acquired Wachovia Bank. The Bank of America absorbed Merryl Lynch. These cases can be considered successful because they prevented the bankruptcy of the acquired banks. The flow of transactions was smooth without affecting financial liabilities of the acquired banks. However, such deals make the banking sector more concentrated. The bail-in tool is more appropriate in this case. If properly implemented, the bail-in mechanism will have a slight effect on competition, while its failure simply eliminates a competitor without consolidating the existing one ${ }^{17}$.

Rating agencies' response is another issue relating to the bail-in mechanism. In 2014, Standard and Poor's reported that banks' liabilities would be assigned from

\footnotetext{
${ }^{16}$ EU regulators tell 11 countries to adopt bank bail-in rules. Available at: http://www.businessinsider.com/r-eu-regulators-tell-11countries-to-adopt-bank-bail-in-rules-2015-5

${ }^{17}$ Sommer J.H. Why Bail-In? And How! FRBNY Economic Policy Review, 2014, December, pp. 207-228.
} 
taxpayers to shareholders and holders of bank bonds, thus influencing ratings of financial institutions. The extent to which such transfer affects ratings will depend on how each EU country adapts new EU Bank Recovery and Resolution Directives (BRRD). According to S\&P, the BRRD downgrade the predictability of banking systems in those countries that are teetering on the brink of bail-in ${ }^{18}$. Subsequently, in early 2015, S\&P reduces ratings of major banks of the United Kingdom, Germany, Switzerland and Austria, thus decreasing long-term credit ratings of Barclays Plc, Credit Suisse Group AG, HSBC Holdings Plc, Lloyds Banking Group, Royal Bank of Scotland Group Plc and Standard Chartered Plc. As S\&P reports, it happened because an urgent aid of the State became less probable for the above banks, and there was not an exact model outlining how new laws would be particularly enforced ${ }^{19}$.

New bank regulation rules complemented with the bail-in provision induce political complications that take various shapes in the EU countries. Rating agencies are wondering how banks' losses will be apportioned to retail investors, which are situated in different countries. In early 2016, Fitch stated in this respect, that the implementation of such provisions and principles will face some difficulties, since losses on retail investors may be politically unacceptable in some European countries, mentioning Portugal and Italy, in particular. According to the Vice-President of Moody's Rating Agency, significant differences between retail and large investors logically necessitate the bail-in mechanism only in relation to the latter ${ }^{20}$.

International agencies have already commented news on the possible use of the bail-in mechanism in Russia. As mentioned by Fitch, ratings assigned to the Russian banks do not allow for the sovereign support factor and recent steps for bail-in adoption make this support even less probable. However, authorities' intentions to use the bail-in tool shall be construed in the context of declining probability of the State aid to ill-managed banks. The positive aspect is that authorities attempt to standardize procedures for handling issues with failing banks ${ }^{21}$. The Russian privately-owned banks are ranked within BB+ through B- in line with the banks' solvency $^{22}$. Therefore, currently experts are divergent whether bail-in influences the ratings of the Russian banking institutions. If it does, how great this impact will be?

As a conclusion, it is worth mentioning that the use of the bail-in tool in Russia will definitely provoke further changes. As the first and foremost, authorities will try to dissuade major depositors (entities or individuals from holding their funds with banks). However, it is difficult to assure that would-be depositors will opt for more stable banks after they withdraw their money from risk-exposed banks, since the capital outflow from the country may subsequently grow or stream into the shadow segment. It is unclear insofar about the conversion moment, the amount to be converted and the amount to be disbursed to would-be investors for the risk. Furthermore, it is necessary to be prepared for a swift response and steps in case of serious troubles with the bank. The cost of converting funds into the capital also seems to be disputable. Another possible difficulty hides behind a question as to how the bail-in mechanism will influence ratings international rating agencies assign to banks. It also seems unreasonable to equate ordinary deposits with such instruments. It would be more logic to create separate instruments, which investors would be interested in. Mitigating risks for the economy is the main point to remember in such circumstances. It would be sensible to borrow the EU expertise and practices of preventive measures, when banks submit to supervisory bodies their action plans if the economic situation aggravates nationwide and worldwide.

\footnotetext{
${ }^{18} \mathrm{New}$ directive shifts risk from taxpayers to shareholders and bondholders. Available at: http://www.praguepost.com/finance/41847report-three-countries-to-apply-bail-in-rules-early

${ }^{19}$ S\&P snizilo reitningi krupneishikh evropeiskikh bankov [S\&P downgraded ratings of the largest European banks]. Available at: http://www.warandpeace.ru/ru/news/view/98072/ (In Russ.)

${ }^{20}$ Hale T. Rating Agencies Warn on Bank Bail-In Rules. Available at: http://www.ft.com/cms/s/0/55c6fa9c-baaa-11e5-b1518e15c9a029fb.html
}

\footnotetext{
${ }^{21}$ Fitch: vozmozhnoe vvedenie bail-in v RF govorit o veroyatnom snizhenii gospodderzhki bankov [Fitch: Probable adoption of bail-in is evidence of reduction in the State aid to banks]. Available at: http://tass.ru/ekonomika/2652722 (In Russ.)

${ }^{22}$ Pri vvedenii mekhanizma bail-in reitingi bankov ne snizyatsya [Bail-in will not drive banks' ratings down]. Available at: http://bankir.ru/novosti/20160210/pri-vvedenii-mekhanizma-bail-inreitingi-bankov-ne-snizyatsya-10115796/ (In Russ.)
} 


\section{Figure 1}

The number of licenses revoked by the Bank of Russia within 2001-2015

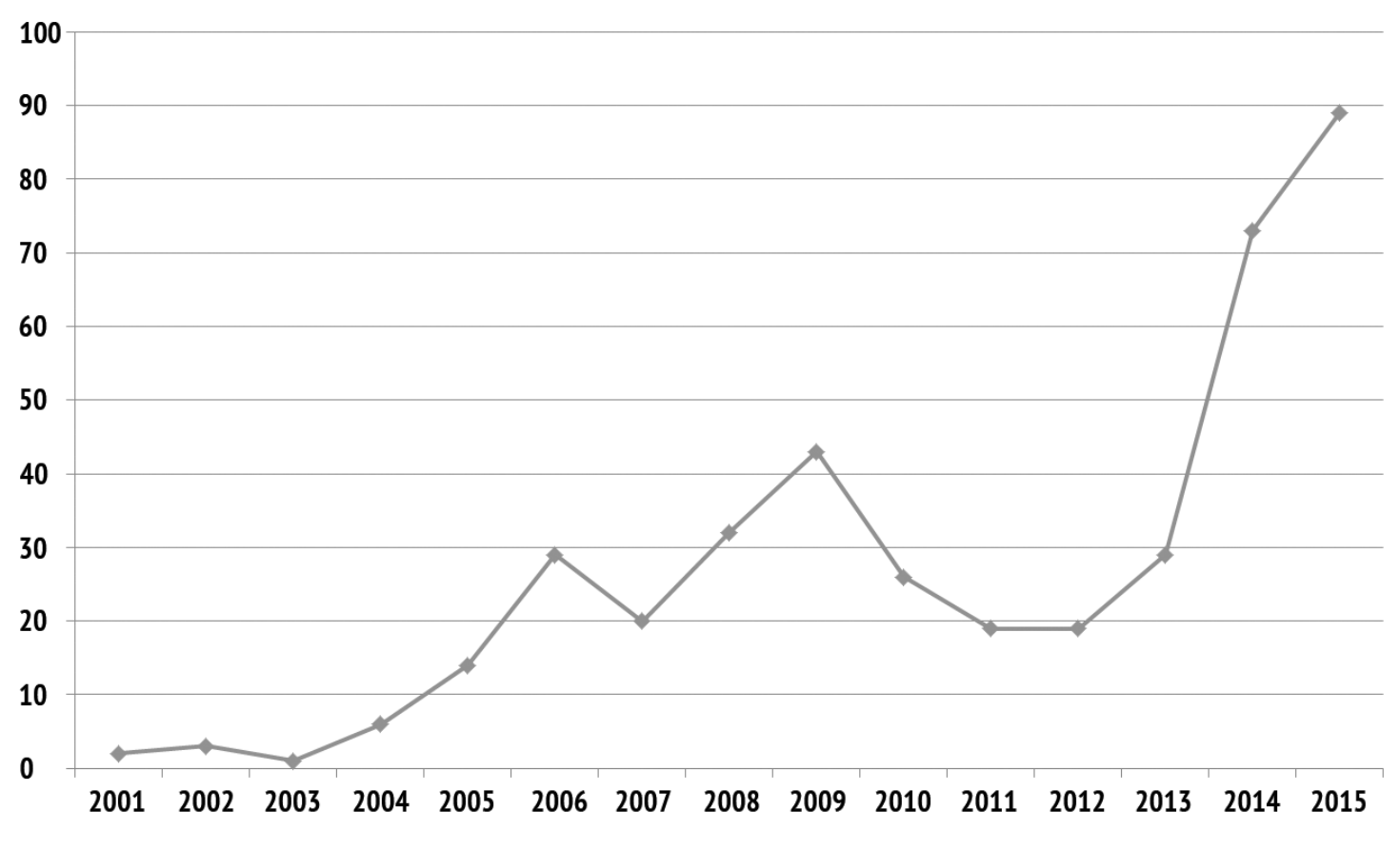

Source:COMBANKS.RU.Available at: http://www.combanks.ru/nolicense/?q=2003 (In Russ.)

\section{Figure 2}

Insurance recovery paid out by the Deposit Insurance Agency (2010-2016), billion RUB

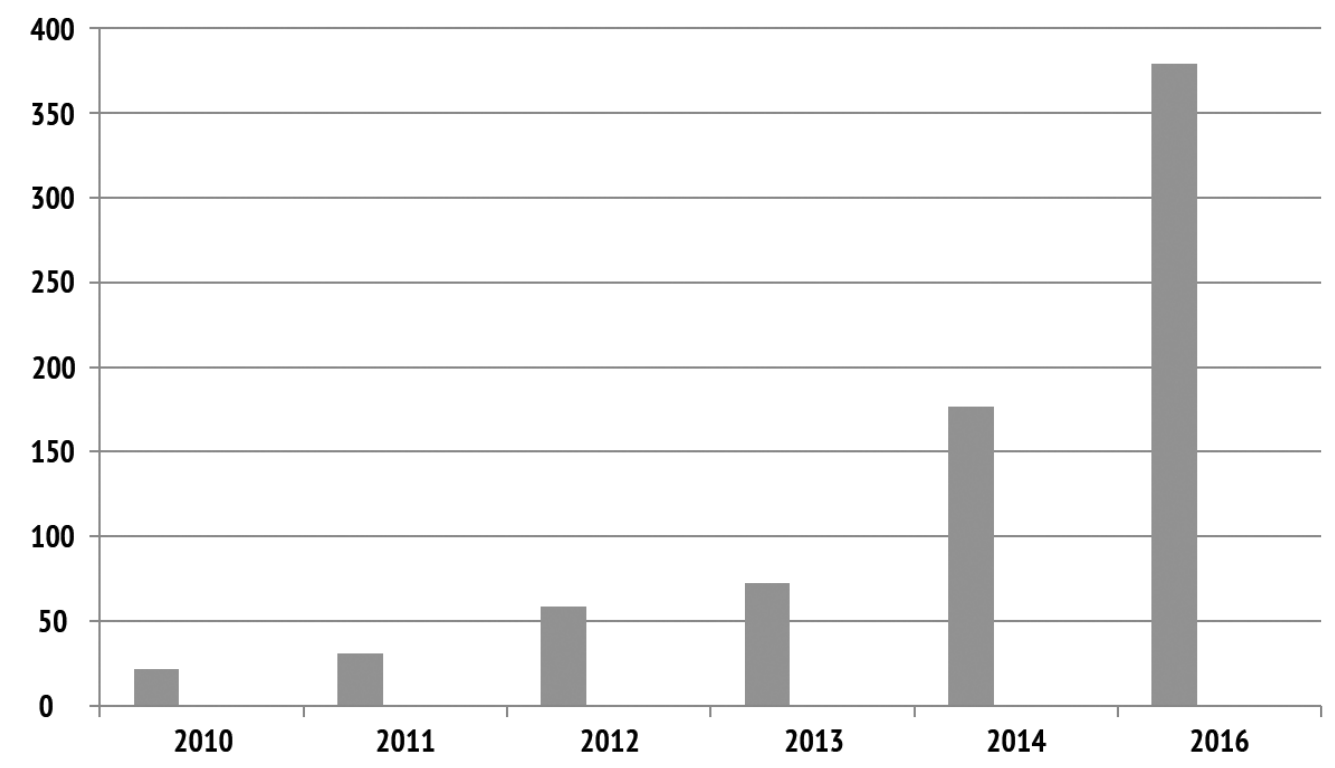

Source:Deposit Insurance Agency. Available at: http://www.asv.org.ru/agency (In Russ.) 


\section{References}

1. Dzhagityan E.P. [Financial Stability Board: Is institutionalization a reality?]. Mirovaya ekonomika i mezhdunarodnye otnosheniya = World Economy and International Relations, 2015, no. 11, pp. 78-90. (In Russ.)

2. Dzhagityan E.P., Sil'vestrov S.N. [A shift of the U.S. banking regulation paradigm: From short-term benefits to long-term risk management priorities]. Den'gi $i$ kredit = Money and Credit, 2013, no. 8, pp. 53-61. (In Russ.)

3. Volkova A.N., Nezamaikov I.S. [Bank license withdrawal. Why the Bank of Russia revokes licenses?]. Vestnik nauki i tvorchestva, 2016, no. 4, pp. 47-52. (In Russ.) Available at: http://elibrary.ru/contents.asp? issueid $=1577170$

4. Pakhomova S.A. [Grounds for banking license revocation in the Russian Federation]. Molodoi uchenyi = Young Scientist, 2015, no. 24, pp. 526-529. (In Russ.)

5. Genkin A.S. [Depositors and banks: Arising problems and constructive solutions]. Bankovskie uslugi = Banking Services, 2016, no. 2, pp. 33-36. (In Russ.)

6. Zalibekova D.Z. [Depositor protection issues]. Teoriya i praktika obshchestvennogo razvitiya = Theory and Practice of Social Development, 2014, no. 15, pp. 106-108. (In Russ.)

7. Dmitriev I.V. [Increasing the trust in the banking sector and developing the deposit insurance system in Russia]. Vestnik MGIMO Universiteta = Vestnik MGIMO-University, 2014, no. 1, pp. 158-163. (In Russ.)

8. Akramov T.R. [Deposit insurance scheme as an element of sustainability of the banking sector]. Den'gi $i$ kredit = Money and Credit, 2013, no. 6, pp. 55-58. (In Russ.)

9. Altynnikova L.A., Nikeenko T.A. [Deposit insurance system in Russia: Main shortcomings and areas for development]. Ekonomicheskaya sreda = Economic Environment, 2014, no. 2, pp. 128-131. (In Russ.)

10. Mateikovich M.S., Kirakosyan A.V. [Deposit insurance scheme: Theory and practice]. Vestnik Tyumenskogo Gosudarstvennogo universiteta. Sotsial'no-ekonomicheskie i pravovye issledovaniya = Bulletin of Tyumen State University. Socio-Economic and Legal Studies, 2011, no. 3, pp. 146-153. (In Russ.)

11. Tulyai E.Yu. [The deposit insurance system under the banking crisis]. Pravovye problemy ukrepleniya Rossiiskoi gosudarstvennosti: materialy Vserossiiskoi nauchno-prakticheskoi konferentsii [Proc. All-Russian Sci. Conf. Legal Problems of Strengthening the National Identity of Russia]. Tomsk, Tomsk University Publ., 2015, pp. $127-130$. (In Russ.)

12. Kovalev A.E. The Issue of Economic Justice of Bail-In Use in Rehabilitation of 'Weak' Banks. Innovatsionnaya nauka = Innovative Science, 2016, no. 3-1, pp. 127-128.

13. Sommer J.H. Why Bail-In? And How! FRBNY Economic Policy Review, 2014, vol. 20, no. 2, pp. $207-228$.

14. Smyslov D.V. [G20 Saint Petersburg summit]. Mirovaya ekonomika i mezhdunarodnye otnosheniya $=$ World Economy and International Relations, 2014, no. 12, pp. 15-25. (In Russ.)

15. Akramov A.R. [Commercial banks' bankruptcy prevention measures: Evolution of institutions and mechanisms]. Den'gi i kredit = Money and Credit, 2013, no. 8, pp. 21-26. (In Russ.)

16. Timokhina A.V. [A modern approach to the 'too big to fail' problem in the financial sector]. Bankovskie us/ugi $=$ Banking Services, 2013, no. 5, pp. 18-22. (In Russ.)

17. Kornivskaya V.O. [Minimizing the participation of the State in the support to depressed financial institutions: European experience in the context of Ukrainian realities]. Ekonomicheskaya teoriya = Economic Theory, 2015, vol. 12, no. 2, pp. 63-77. (In Russ.)

18. Shabaeva V.I., Dunkel' G. [A single mechanism for rehabilitation of troubled banks in Europe: Assessment of the proposal to the EU Commission]. Sotsial'nye i gumanitarnye nauki. Otechestvennaya i zarubezhnaya literatura. Seriya 2: Ekonomika = Social and Human Sciences. Domestic and Foreign Literature. Series 2: Economics, 2014, no. 2, pp. 88-92. (In Russ.) 
19. Melaschenko P., Reynolds N. A Template for Recapitalising Too-Big-to-Fail Banks. BIS Quarterly Review, 2013, no. 6, pp. 25-39.

\section{Conflict-of-interest notification}

I, the author of this article, bindingly and explicitly declare of the partial and total lack of actual or potential conflict of interest with any other third party whatsoever, which may arise as a result of the publication of this article. This statement relates to the study, data collection and interpretation, writing and preparation of the article, and the decision to submit the manuscript for publication. 